\title{
Organizações Regionais e Processos de Prevenção, Gestão e Resolução de Conflitos em África: Experiências da SADC, CEDEAO e IGAD
}

Regional Organizations and Processes of Prevention, Management and Resolution Conflicts in Africa: SADC, ECOWAS and IGAD Experiences

\section{Emílio Jovando Zeca ${ }^{1}$}

\section{Resumo}

O trabalho discute o papel das organizações regionais africanas - SADC, CEDEAO $e$ IAGAD - nos processos de prevenção, gestão e resolução de conflitos internos. $O$ estudo constata que em situações de conflitos intraestatais, as organizações regionais têm dificuldades de lidar com os casos, ao passo que nos interestatais, devido aos compromissos formais com a organização, é mais fácil usar os mecanismos de resolução pacífica de conflitos ou intervenções militares.

Palavras-Chave: Organizações Regionais; Resolução de Conflitos; Conflitos Africanos.

\begin{abstract}
This article discusses about the role of African regional organizations - SADC, ECOWAS and IAGAD - in the processes of internal conflicts resolution. The study notes that in cases of intra-State conflicts, the regional organizations have difficulties to solve it. However, in the inter-State conflicts, because of formal commitments, the regional organizations easily use the peaceful settlement mechanisms to solve conflicts or military interventions.
\end{abstract}

Keywords: Regional Organizations; Conflict Resolution; African conflicts.

\section{Introdução}

O presente artigo apresenta uma discussão sobre os contornos do papel das organizações regionais africanas nos processos de prevenção, gestão e resolução de conflitos internos, na África, com enfoque para as experiências da Comundiade Para o Desenvolvimento da África Austral (SADC), Comunidade Econômica Para o Desenvolvimento da África Ocidental (CEDEAO) e Autoridade Intergovernamental para

\footnotetext{
${ }^{1}$ Doutorando do PPGEEI/UFRGS - Programa de Pós Graduação em Estudos Estratégicos Internacionais da Universidade Federal do Rio Grande do Sul; Pesquisador do Centro de Estudos Estratégicos e Internacionais CEEI/ISRI de Moçambique; Graduado em Relações Internacionais e Diplomacia pelo Instituto Superior de Relações Internacionais de Moçambique; Mestre em Resolução de Conflitos e Mediação; Especialização em Segurança Nacional e Direito à Informação; Email: emiliojobando@ gmail.com
} 
o Desenvolvimento (IAGAD), visto que a paz, estabilidade e segurança são três fenômenos que poucos Estados africanos experimentaram, desde o início do processo das independências africanas, na década de 1960. Sempre que um dos três fenómenos acima apresentados apareceu, foi apenas por um curto intervalo de tempo, suficiente para reacender uma disputa, um conflito violento nacional ou internacionalizado ou até mesmo uma guerra ou outras formas de violência política organizada. Diversos autores apontam para problemas relacionados com a herança colonial - delimitação de fronteiras artificiais que separaram grupos étnicos - a ganância pelo poder, as situações de corrupção, exclusão étnica e religiosa, entre outros, como principais fatores por detrás destas tendências violentas e conflituosas de atuação nos e entre os Estados africanos.

Logo que foi criada a Organização da Unidade Africana (OUA), em 1963, como um mecanismo que os Estados africanos encontraram para viabilizar a convergência e materialização dos interesses e objetivos comuns dos Estados africanos independentes do sistema colonial, a prevenção, gestão e resolução de conflitos foi uma prioridade. Como resultado, foi criada a Comissão de Mediação, Conciliação e Arbitragem de Conflitos da OUA. Todavia, a materialização do mandato visionário dessa comissão foi minada pelos princípios estabelecidos pelo Artigo $3^{\text {o }}$ da Carta da OUA, que previa igualdade soberana dos Estados Membros, não interferência nos assuntos internos dos Estados, respeito pela soberania e integridade territorial - Princípio de Intangibilidade das Fronteiras ${ }^{2}$ - direito inalienável da independência, solução pacífica de controvérsias, condenação de assassinatos políticos e atividades subversivas; emancipação dos Estados não independentes e a afirmação de uma política de não alinhamento em relação a todos blocos vigentes no período da Guerra Fria.

Em termos práticos, esses princípios acima mencionados deram sempre primazia aos mecanismos pacíficos de resolução de conflitos e a sua materialização foi sempre condicionada pela fraca vontade política dos Estados Membros da OUA em estabelecer mecanismos com poder efetivo - instituições, tratados e diretrizes - para que houvesse capacidade de se cumprir o estabelecido pela Carta da OUA. Depois de várias tentativas em superar os constrangimentos dos princípios da Carta da OUA,

\footnotetext{
${ }^{2}$ Princípio utti possidetis, uti possidetis iuris.
} 
somente com a Criação da União Africana, em 2002 e o seu respectivo Conselho de Paz e Segurança, é que foi possível criar condições para que houvesse efetividade nos mecanismos pacíficos de prevenção, gestão e resolução de conflitos e que fossem combinados com o uso da força, através da instauração do princípio de intervenção militar em situações específicas, para que a atuação da organização continental africana sofresse mudanças significativas na sua normatividade e atuação. Não obstante a esse avanço verificado com a instauração do princípio do intervencionismo, ainda persistem desafios enormes para que tanto a União Africana, quanto as organizações regionais possam cumprir os seus papéis, enquanto agentes que previnam, gerem e resolvem conflitos internos na África de forma efetiva e eficaz, criando condições para a construção e consolidação da paz nos Estados africanos.

Baseando-se numa metodologia qualitativa, assente no método histórico, observação participante dos fatos e pesquisa bibliográfica, o trabalho está estruturado em duas grandes partes, compostas por cinco sessões, antecedidas da introdução e seguidas das considerações finais e referências bibliográficas. A primeira parte discute a problemática dos conflitos internos, na África, e é composta pela sessão que debruça sobre os conflitos intraestatais e interestatais africanos e o papel das organizações regionais na sua prevenção, gestão e resolução. A segunda parte apresenta as experiências de prevenção, gestão e resolução de conflitos levadas a cabo por três organizações regionais africanas, nomeadamente, SADC, CEDEAO e IGAD.

No final da análise, constata-se que não obstante ao quadro pessimista sobre a situação de ocorrência de conflitos internos na África e as limitações que as organizações regionais possuem para intervir nos mesmos, várias são as iniciativas levadas a cabo pela União Africana e pelos blocos regionais africanos com vista a prevenir, gerir e resolver os conflitos internos, sobretudo com recurso aos métodos pacíficos e diplomáticos de resolução de conflitos nos diversos casos. Desta feita, as próprias organizações regionais africanas, enquanto mecanismos de integração regional operam como instrumentos de cooperação, integração e prevenção, gestão e resolução de conflitos, uma vez que elas surgiram, por um lado, como mecanismos de promoção da cooperação e integração regional de forma gradualista, e por outro, como instrumentos para impedir a eclosão de conflitos violentos. Todos esses aspetos estão 
integrados na grande estratégia de promoção da paz, segurança e desenvolvimento nos diversos blocos regionais de integração da África.

\section{Conflitos Intraestatais e Interestatais na África}

O continente africano tem sido marcado por conflitos internos e internacionalizados ${ }^{3}$, logo depois do surgimento das primeiras experiências de independência na África, na década de 1960. Desde esse período, vários conflitos internos surgiram e foram motivados por vários fatores isolados ou combinados. A maioria dos Estados africanos experimentou, pelo menos, uma situação de conflito interno ou interestatal, cujas causas estiveram relacionadas a herança colonial das questões de fronteiras, a partilha do poder, erosão da legitimidade, mudanças constitucionais inconstitucionais, transições democráticas e processos eleitorais mal sucedidos, o acesso aos recursos financeiros e naturais, entre outros fatores. Esses conflitos internos tiveram várias intensidades, onde uns foram capazes de desmoronar a autoridade central dos seus Estados, como é o caso da Somália, na década de 1990, ou da Líbia mais recentemente.

Não há dúvidas que a colonização europeia tem fortes ligações com a situação dos conflitos internos na África, porque dividiu profundamente as sociedades africanas - "dividir para reinar" - mas as lideranças africanas também tem cota parte no processo, porque nas últimas cinco décadas do Século XX pouco fizeram para inverter esse cenário desfavorável, ignorando por completo os interesses coletivos e supremos africanos que guiaram as lutas de libertação nacional dos povos africanos, pelos interesses individuais e grupais, bem como pelas facilidades que o poder oferece, negligenciando por completo as aspirações, interesses e objetivos coletivos. Os grupos étnicos foram manipulados pelas lideranças, para a prossecução de interesses

\footnotetext{
${ }^{3} \mathrm{O}$ conflito intra-estatal também é denominado interno que para DAVID (2000, p. 111 e 134), envolve o Estado e atores não-estatais, ou grupos sub-nacionais, em que estes últimos não só se combatem entre si, como também contestam e combatem o seu próprio Estado, facções, etnias que procuram manter ou obter o controlo do território e do poder político e desenrolam no interior dos Estados. Estes conflitos devem ser vistos de uma forma holística, uma vez que os factores internos interagem diretamente com os externos no contexto e dinâmica internacional. Há casos em que os conflitos internos obrigam várias formas de intervenção. O conflito intra-estatal é também designado conflito internacional. A Corte de Haia (1907) define Conflito Internacional como sendo todo o desacordo sobre certo ponto de direito, juri, ou de facto, factus, e toda contradição ou oposição de teses jurídicas ou de interesses entre dois ou mais Estados. O conflito internacional pode também ter como partes interessadas entes de direito internacional, como é o caso das organizações internacionais ou outro sujeito de direito internacional (CAVALCANTE, 201, p. 12).
} 
inconfessos ou foram colocados a lutar entre si, numa espécie de "violência em estado natural e que se inclina diante de uma violência maior" como aponta Fanon (1968, p. 38).

A luta pelos recursos financeiros e naturais, bem como pelo poder político foi o que mais originou o surgimento de diversos conflitos nos e entre Estados na África. A governação política baseada na exclusão de grupos étnicos e diversos segmentos da sociedade e do Estado, a personalização do poder e a manutenção do mesmo como recurso a ameaça ou uso efetivo da violência, também estão na origem dos referidos conflitos. 0 envolvimento externo foi quase que sempre um catalisador para o surgimento e exacerbação de conflitos violentos na África, numa espécie de instigação, como pontua Herbst (2000), ao referir-se que "a longa crise econômica que muitos Estados africanos enfrentaram, desde os finais dos anos 1970, causou uma profunda erosão da base de rendimento de muitos governos e, consequentemente, a sua capacidade de projetar poder" (BERBST, 2000, p. 19).

Para além das crises econômicas, a realidade apresenta outros fatores que podem estar por detrás da eclosão de conflitos internos na África. A realidade interna de cada Estado proporcionou a eclosão de conflitos específicos. Os desequilíbrios regionais, a exclusão política, os mecanismos de acesso, controle e manutenção do poder político, a corrupção, entre outros aspetos podem estar por trás da eclosão de diversos tipos de conflitos nos Estados africanos. Todavia, um aspeto importante a se ter em conta é que não obstante a sua dimensão interna, muitos dos conflitos africanos tem a capacidade de provocar desequilíbrios e instabilidade regional, através da intensidade da violência organizada, criando deslocados e refugiados de guerras e crises políticas.

A tabela, abaixo, apresenta de forma resumida, um conjunto de conflitos internos que ocorrem na África, desde meados da década de 1960 até a segunda década dos anos 2000, abarcando um período que comporta cinco décadas.

Tabela 1: Principais Conflitos Intraestatais e Interestatais em África

\begin{tabular}{|c|c|c|}
\hline Ano & Principais Conflitos & \multicolumn{1}{c|}{ Local } \\
\hline $\mathbf{1 9 6 1}$ & Reivindicações de Independência da Região Britânica. & Camarões \\
\hline
\end{tabular}




\begin{tabular}{|c|c|c|}
\hline 1975 & $\begin{array}{l}\text { Conflito de Secessão e Recursos em Cabinda; Conflito } \\
\text { MPLA e UNITA. }\end{array}$ & Angola \\
\hline 1975 & Conflito no Sahara Ocidental. & Marrocos \\
\hline 1976 & Guerra dos 16 Anos. & Moçambique \\
\hline 1976 & Guerra de Secessão do Biafra. & Nigéria \\
\hline 1978 & Disputa pela Faixa Aouzou. & Chade e Líbia \\
\hline 1987 & Insurgência do LRA na RDC, RCA e Sudão do Sul. & Grandes Lago \\
\hline 1991 & Guerra Civil na Somália, na Somália e Quénia. & $\begin{array}{l}\text { Chifre de } \\
\text { África }\end{array}$ \\
\hline 1992 & Conflito da Frente de Libertação de Oromo. & Etiópia \\
\hline 1994 & Genocídio de Ruanda: hútus e tutsis. & Ruanda \\
\hline 1995 & Insurgência de Ogaden na Etiópia. & Etiópia \\
\hline 1995 & Segunda Insurgência Afar na Eritreia e Etiópia. & Etiópia \\
\hline 1996 & Insurgência das Forças Aliadas Democráticas. & $\mathrm{RDC}$ \\
\hline 1998 & Conflitos Comunais. & Nigéria \\
\hline 1998 & $\begin{array}{l}\text { Conflito interno entre FR, as Ditadura Militar e Governo } \\
\text { Democrático. }\end{array}$ & Serra Leoa \\
\hline 1999 & Conflito Ituri na RDC. & $\mathrm{RDC}$ \\
\hline 2002 & Insurgência no Magreb em Argélia e Tunísia. & Magreb \\
\hline 2003 & Guerra no Darfur. & Sudão \\
\hline 2004 & Conflito de Kivu na RDC e Burundi. & $\begin{array}{c}\text { Grandes } \\
\text { Lagos }\end{array}$ \\
\hline 2004 & Conflito no Delta do Níger. & Nigéria \\
\hline 2008 & Conflito Pós-Eleitoral. & Zimbábue \\
\hline 2008 & Crise Política. & Madagáscar \\
\hline
\end{tabular}




\begin{tabular}{|c|c|c|}
\hline 2009 & $\begin{array}{l}\text { Insurgência do Boko Haram na Nigéria, Camarões, Níger } \\
\text { e Tchad. }\end{array}$ & Nigeria \\
\hline 2009 & Conflito dos Nómades Sudaneses. & Sudão \\
\hline 2011 & $\begin{array}{l}\text { Intervenção Militar Mudança de Regime e Crise e Guerra } \\
\text { Civil. }\end{array}$ & Líbia \\
\hline 2011 & Conflito no Sul do Cordofão. & Sudão \\
\hline 2012 & Violência Étnica e Guerra Civil no Sul do Sudão. & $\begin{array}{l}\text { Sudão e } \\
\text { Etiópia }\end{array}$ \\
\hline 2012 & Conflito na Republica Centro Africana. & RCA \\
\hline 2012 & Conflito no Norte do Mali. & Malí \\
\hline 2012 & $\begin{array}{l}\text { Disputas fronteiriças no Lago Niassa entre Maláui e } \\
\text { Tanzânia. }\end{array}$ & Africa Austral \\
\hline 2013 & Insurgência da RENAMO, em Moçambique. & Moçambique \\
\hline 2014 & Disputa Pelo Poder entre CDP e o Governo. & Burkina Faso \\
\hline 2015 & Insurgência do ISIL. & Tunísia \\
\hline 2015 & Distúrbios Políticos no Burundi. & Burundi \\
\hline
\end{tabular}

Fonte: Elaborado Pelo Autor (2016).

A maioria dos conflitos, apresentados na tabela acima, tem uma dimensão interna, mas com um enorme potencial para criar desequilíbrios e instabilidade regional, através da intensidade da violência organizada, deslocamento de pessoas, refugiados. Igualmente, na caixa acima pode-se notar que desde a década de 1960 o continente foi assolado por vários tipos de conflitos internos e em todas as suas subregiões continentais. Esses conflitos vão desde conflitos interétnicos e fronteiriços, passando por conflitos secessionistas e separatistas, até aos conflitos relacionados com a a transição política e promoção e proteção dos direitos civis.

Fruto da herança colonial relacionada com fronteiras artificiais, frequentemente há ocorrência de conflitos interétnicos entre grupos que encontram-se 
dentro de fronteiras nacionais de um determinado Estado, bem como entre grupos étnicos que encontram-se separados em dois, três ou mais Estados africanos. Diversos conflitos interestatais têm ocorrido, principalmente, em territórios estratégicos que são disputados por Estados, como são os casos do conflito entre Chade e Líbia sobre a faixa Aouzou, entre 1978 e 1987; a guerra Tanzânia e Uganda que derrubou Idi Amin, em Uganda entre 1978 e 1979; a guerra entre Quênia e Somali, entre 1963-1967; o conflito entre Somália e Etiópia, que decorreu entre 1964 e 1978; o conflito entre Egito e Líbia, em 1977; o conflito fronteiriço entre Eritreia e Etiópia, entre 1998-2000; a disputa entre Camarões e Nigéria sobre a Península de Bakassi, rica em petróleo, em 1994. Para além destes casos, existem diversos outros conflitos interestatais que ocorreram na África, e com manifestações diferentes que vão do estado latente, passando pelo de manifestação não violenta até os que encontram-se no estado de manifestação violenta.

Existem, igualmente, um conjunto de conflitos relacionados com situações secessionistas e separatistas. Estes conflitos, especificamente, não ocorrerem com muita frequência na África, devido ao princípio de intangibilidade das fronteiras instituído pela OUA e reafirmado pela União Africana, em 2002. Todavia, há casos emblemáticos deste tipo de conflitos na África. O primeiro é o caso do conflito do Sahara Ocidental envolvendo Marrocos, cuja origem remonta 1975, e o segundo envolve Camarões, onde a região do Sul, que era domínio britânico, reivindica a instauração da sua independência e soberania da República dos Camarões, desde 1961. Na África, estes conflitos secessionistas e separatistas muitas vezes tem as mesmas caraterísticas que as lutas de libertação nacional, porque os grupos étnicos têm caraterísticas de autênticas nações, na sua concepção tradicional.

A promoção e proteção dos direitos civis tem sido fator de conflitos na África, sobretudo quando se trata de questões relacionadas com a participação política e civil, distribuição e legitimidade do poder político, bem como aspetos relacionados com gestão da coisa pública e governação dos Estados. Este tipo de conflito é bastante recorrente em situações pós eleitorais. Muitos desses conflitos têm uma ligação direta com as falhas da transição política que ocorrerem com maior frequência na década de 1990, em diversos Estados africanos. A transição política para a democracia 
proporcionou conflitos de natureza intraestatal, fruto do aumento de tensões resultantes dos imperativos da democratização da vida social, política e econômica. De acordo com Cohen (1996, p. 6) trata-se de "fenômenos bloqueadores dos sistemas políticos que já não podem resolver as diferenças individuais ou em grupo, através de procedimentos não-violentos". A transição para um sistema de democracia liberal e participativa criou e contínua a criar enormes problemas nos Estados africanos. Apesar do sistema democrático liberal ter triunfado em alguns Estados como Moçambique, Benim, Botsuana, Gana, África do Sul e Tanzânia, se está muito longe de inspirar qualquer esperança para o futuro de regimes democráticos efetivos na África, visto que há sempre tendências de retrocessos na democratização.

Todos os conflitos acima mencionados têm um enorme potencial para inibir o crescimento e desenvolvimento econômico e social, bem como para provocar situações de instabilidade política e insegurança estatal e humana. Tomando consciência de que enquanto os conflitos internos persistirem no continente africano e nas sub-regiões, os projetos de desenvolvimento seriam inviabilizados, as organizações internacionais sub-regionais africanas decidiram criar os seus mecanismos de prevenção, gestão e resolução de conflitos, bem como os de promoção da paz e segurança regional, no âmbito da cooperação para operacionalização da arquitetura de paz e segurança da União Africana. De seguida são apresentados alguns exemplos de prevenção, gestão e resolução de conflitos em África, com a intervenção da União Africana e das organizações de integração regional.

\section{Organizações Regionais e Resolução de Conflitos em África}

As organizações regionais fazem parte do subgrupo das organizações internacionais ${ }^{4}$ classificadas de acordo com questões geográficas e territoriais. Elas abarcam um conjunto de Estados que compõem uma determinada região. As organizações internacionais são associações de Estados, estabelecidas por um acordo entre seus Estados membros com o intuito de atingir objetivos de interesse comum,

\footnotetext{
${ }^{4}$ As organizações internacionais podem ser definidas como "um acordo institucional entre os membros de um sistema internacional, a fim de alcançar os objetivos de acordo com condições sistêmicas, refletindo atributos, aspirações e preocupações dos seus membros" (HANRIEDER, 1966, citado por GABRIELA, 2013, p. 309). Uma regra básica é que os Estados filiados em organizações internacionais, mantém a soberania de Estado-nação (BARKIN e CRONIN, 2009, 107-130, citados por Gabriela, 2013, p. 309).
} 
através da cooperação entre os Estados que a integram, ocorre a facilitação de entendimentos, legitimação, comunicação e a redução de tensões entre os membros (DIAS, 2010, p. 63-65). Através da facilitação, as organizações internacionais oferecem aos Estados membros um marco estabelecido e permanente para o diálogo. A redução de tensões, juntamente com a resolução pacífica de disputas, é uma importante função das organizações internacionais, porque contribui para uma consciencialização da necessidade de entendimentos e equilíbrio na correlação de forças e poder entre os Estados membros.

De modo geral, as organizações internacionais regionais são parte central da política internacional e da vida social em diferentes partes do sistema internacional. Elas constituem uma das formas mais institucionalizadas de realizar a cooperação e a integração internacional, bem como de reduzir situações de conflitos. Isso se dê devido às normas, regras, leis e procedimentos para resolução de disputas, ajuda humanitária, utilização de força militar, programas de assistência ao desenvolvimento, mecanismos para coleta de informações que são algumas das práticas que produzem os moldes da sua governação (HERZ e HOFFMANN, 2004, p. 1-16). Dessa forma, as organizações internacionais favorecem a legitimação de normas e regras que para a maior parte dos atores que a compõem devem ser respeitadas, gerando um sentimento de obrigação moral dos membros.

A história das organizações internacionais demonstra que elas usaram tanto meios pacíficos de resolução de conflitos, quanto leis e recursos a força para prevenir, gerir e resolver conflitos, fruto daquilo que Dias (2010, p. 64) refere como sendo "poderes que lhes são conferidos para aturarem no seu âmbito de atuações fundamentais para o cumprimento de sua missão". A maioria dos tratados que criam as organizações internacionais, no geral, preconizam a resolução de disputas com recurso a mediação ${ }^{5}$, facilitação ${ }^{6}$, bons ofícios ${ }^{7}$, arbitragem $^{8}$ e outros meios diplomáticos e jurídicos para resolver conflitos entre Estados membros.

\footnotetext{
${ }^{5}$ Mediação é baseada em regras e procedimentos preestabelecidos. O objetivo do mediador é de ajudar as partes a negociar de maneira mais efetiva. O mediador não impõe a solução. Sua função é ajudar na buscar do melhor caminho para se chegar a um acordo (MARTINELLI e ALEMEIDA, 1998, p. 73).

${ }^{6}$ Facilitação é um processo e assistência, semelhante à mediação nos seus objetivos. No entanto, o processo facilitação geralmente, não responde a um procedimento rigidamente definido. Neste processo, o facilitador trabalha com as partes para melhorar a eficácia da comunicação e a capacidade de resolver problemas. O
} 
Os mecanismos de resolução pacífica de conflitos perfazem o que se apelida de diplomacia preventiva, ou seja, um conjunto de mecanismos que visam à prevenção do surgimento de conflitos, por um lado, e o impedimento da sua deflagração e alastramento, por outro. Para Bourton (1990, p.18), a prevenção de conflitos tem a ver com um conjunto de processos e procedimentos com vista a redução das condições causais e a promoção positiva de um ambiente conducente a um relacionamento colaborativo entre partes em conflito. Este processo preocupa-se com os problemas sociais e as alterações do ambiente que conduz ao conflito, bem como com a criação de condições que mitigam o mesmo conflito.

Por seu turno, a gestão de conflito se refere ao processo caracterizado por tomada de medidas que visam evitar a escalada do conflito. Desencadeiam-se ações que permitam estabelecer um controle sobre o conflito, de modo a evitar que o mesmo assuma níveis incontroláveis. Este processo abrange a regulação do conflito usando todas as medidas e formas de intervenção da terceira parte (GASPAR, 2003, p. 27 e GASPAR, 2004, p. 36). Enquanto isso, a resolução de Conflitos é um processo que implica aceitar que o conflito pode ser resolvido quando são abordadas as suas causas essenciais. $\mathrm{O}$ conceito está associado a uma abordagem centrada na identificação das causas profundas e na procura de soluções através de um processo de resolução conjunta dos problemas (ONU, 2001, p. 7). Portanto, a resolução de conflitos trata-se de um processo que consiste na identificação e análise das principais causas que deram origem ao conflito, para depois ultrapassá-las. Esse processo procura salvaguardar os interesses das partes de modo a chegar-se a um ponto crítico de satisfação mútua.

facilitador pode ser um terceiro ou uma pessoa pertencente a um dos grupos que seja capaz de oferecer assistência em termos de procedimento e que consiga abster-se de entrar na essência da discussão (ONU, 2001. p. 8).

${ }^{7}$ Bons ofícios consistem em procurar aproximar as partes em conflito, oferecendo-lhes assistência que pode incluir o local para a realização de um encontro para um frente-a-frente. A terceira parte, algumas vezes, serve de elo de ligação entre as partes em conflito. Esta missão pode ser realizada por uma personalidade credível e idónea. A individualidade atua como um intermediário no processo negocial, sobretudo para criar condições para que os primeiros contactos entre as partes tenham lugar (GASPAR, 2004, p. 38).

${ }^{8}$ Arbitragem é considerada a forma mais comum de resolução de conflitos através de uma terceira parte (MARTINELLI e ALMEIDA, 1998, p. 75). Ela é um dos meios mais antigos de resolução de controvérsias que se caracteriza por ser um procedimento através do qual as partes em conflito escolhem um árbitro ou um tribunal composto de várias pessoas neutras e imparciais, para dirimir um litígio, segundo procedimentos estabelecidos por eles ou fixados pelo árbitro ou por uma delegação. 
A prevenção, resolução, gestão de conflitos constituem mecanismos com vista a impedir que os conflitos violentos ocorram ou, em caso da sua ocorrência, que eles não tomem proporções e contornos incontroláveis. Depois da resolução de conflitos, existe a fase de transformação dos conflitos, que é uma atividade que visa alterar os padrões de relacionamento entre as partes depois da resolução do mesmo. Todos esses mecanismos que são discutidos aqui são fundamentais para a compreensão do processo de controle e gestão dos conflitos, de modo que as suas consequências sejam mais positivas do que negativas.

Importa referir que, de acordo com a natureza do conflito, a organização internacional regional pode ter maior ou menor capacidade para prevenir, gerir e resolver. Normalmente, os conflitos interestatais são mais fáceis de serem revolvidos pelas organizações internacionais do que os conflitos intraestatais. Os atores envolvidos nos conflitos intraestatais não tem compromissos com as organizações internacionais, ao passo que os atores envolvidos em conflitos interestatais possuem um conjunto de compromissos e obrigações para com determinadas organizações internacionais, visto que como pontua WILLIAMSON (1985), citado por GABRIELA (2013, p. 311), "a estrutura das organizações internacionais, sobretudo as regionais, influencia a evolução da cooperação interestatal e adapta-se às circunstâncias específicas e a maioria das organizações internacionais desempenha funções de apoio à cooperação entre as cimeiras que tratam de questões muito importantes, assim como a execução de um conjunto de regulamentos". Desta feita, as organizações internacionais regionais têm mais facilidades de intervir, sobretudo com recursos a meios pacíficos de prevenção, gestão e resolução de conflitos, em conflitos interestatais do que nos intraestatais. Neste último tipo, as organizações internacionais regionais, normalmente, intervêm com recurso ao uso da força em solicitação do Estados membro, contra grupos internos que põem em causa a sua soberania e integridade

$\mathrm{Na}$ África as iniciativas de congregação dos Estados em organizações internacionais surgem logo depois do início dos processos de independência do sistema colonial, na década de 1960. Os Estados africanos desde cedo perceberam que possuíam pouco poder efetivo no sistema internacional e que era preciso que fosse levado a cabo um conjunto de ações coletivas, para defender seus interesses coletivos e 
seus objetivos comuns. Essa consciência levou a criação da OUA, em 1963, que depois transformou-se na União Africana em 2002, como foi referido anteriormente e será tratado posteriormente. Enquanto isso, houveram várias iniciativas de criação de organizações internacionais regionais africanas, conhecidas como blocos regionais africanos, que iriam ser os principais atores da integração regional nas sub-regiões africanas, afim de viabilizar a integração continental, bem como atuariam como atores da estratégia de desenvolvimento do continente nos pontos específicos.

As iniciativas de criação de blocos regionais foram consagradas no famoso Plano de Ação de Lagos de 1980 e no Tratado de Abuja de 1991, cujos objetivos centrais estavam voltados para o estabelecimento de Comunidades Econômicas Africanas que são apresentadas na tabela, abaixo, tendo em conta as suas principais regiões onde são apresentados os nomes das organizações regionais, o ano da sua fundação, os Estados membros e os seus principais objetivos que elas se propõem a materializar.

\begin{tabular}{|c|c|c|c|}
\hline \multicolumn{4}{|c|}{ Tabela 2: Blocos Regionais Africanos } \\
\hline Organização & Fundação & $\begin{array}{l}\text { Estados } \\
\text { Membros }\end{array}$ & Objetivos Principais \\
\hline $\begin{array}{c}\text { União Árabe do } \\
\text { Magreb }\end{array}$ & 1989 & $\begin{array}{c}\text { Algéria, Líbia, } \\
\text { Mauritânia, } \\
\text { Morrocco e } \\
\text { Túnisia }\end{array}$ & $\begin{array}{l}\text { Consolidação das relações } \\
\text { fraternais de ligação dos } \\
\text { Estados membros e os seus } \\
\text { povos; realização do } \\
\text { progresso e bem-estar das } \\
\text { suas comunidades e defender } \\
\text { os seus direitos; realização } \\
\text { progressiva da livre } \\
\text { circulação de pessoas, } \\
\text { serviços, mercadorias e } \\
\text { capitais entre Estados } \\
\text { membros; adopção de uma } \\
\text { política comum em todas as }\end{array}$ \\
\hline
\end{tabular}




\begin{tabular}{|c|c|c|c|}
\hline & & & áreas, entre outros. \\
\hline $\begin{array}{l}\text { Comunidade Para } \\
\text { Económica da } \\
\text { África Ocidental }\end{array}$ & 1975 & $\begin{array}{l}\text { Benim, Burquina } \\
\text { Faso, Costa do } \\
\text { Marfim, Cabo } \\
\text { Verde, Gâmbia, } \\
\text { Gana, Guiné } \\
\text { Conacri, Guiné } \\
\text { Bissau, Libéria, } \\
\text { Mali, Níger, } \\
\text { Nigéria, Senegal, } \\
\text { Serra Leoa e } \\
\text { Togo. }\end{array}$ & $\begin{array}{l}\text { Harmonização e coordenação } \\
\text { de políticas nacionais e } \\
\text { promoção da integração de } \\
\text { projetos erividades } \\
\text { relacionadas com agricultura } \\
\text { e recursos naturais, indústria, } \\
\text { transportes e comunicações, } \\
\text { energia, comércio, finanças, } \\
\text { tributação, políticas de } \\
\text { reforma económica, recursos } \\
\text { humanos, } \\
\text { informação, cultura, ciência, } \\
\text { tecnologia, serviços, saúde, } \\
\text { turismo, questões legais; a } \\
\text { harmonização e coordenação } \\
\text { de políticas para a proteção } \\
\text { do ambiente; promoção da } \\
\text { criação de produção } \\
\text { conjunta; a criação de um } \\
\text { mercado comum, através, } \\
\text { entre outros. }\end{array}$ \\
\hline $\begin{array}{l}\text { Comunidade } \\
\text { Económica da } \\
\text { África Central }\end{array}$ & 1981 & $\begin{array}{c}\text { Burundi, } \\
\text { Camarões, } \\
\text { República } \\
\text { Centro-Africana, } \\
\text { Chade, Congo, } \\
\text { Guiné Equatorial, } \\
\text { Gabão, Ruanda, } \\
\text { São Tomé e }\end{array}$ & $\begin{array}{l}\text { Promoção da cooperação e } \\
\text { desenvolvimento } \\
\text { autossustentável, } \\
\text { particular êm } \\
\text { estabilidade econômica e } \\
\text { melhoria da qualidade de } \\
\text { vida dos cidadãos dos } \\
\text { Estados membros da }\end{array}$ \\
\hline
\end{tabular}




\begin{tabular}{|c|c|c|c|}
\hline & & $\begin{array}{c}\text { Príncipe, } \\
\text { República } \\
\text { Democrática do } \\
\text { Congo e Angola. }\end{array}$ & organização, entre outros. \\
\hline $\begin{array}{c}\text { Autoridade } \\
\text { Intergovernamental } \\
\text { para o } \\
\text { Desenvolvimento }\end{array}$ & 1986 & $\begin{array}{l}\text { Djibouti, Etiópia, } \\
\text { Eritreia, Quénia, } \\
\text { Somália, Sudão, } \\
\text { Uganda e Sudão } \\
\text { do Sul. }\end{array}$ & 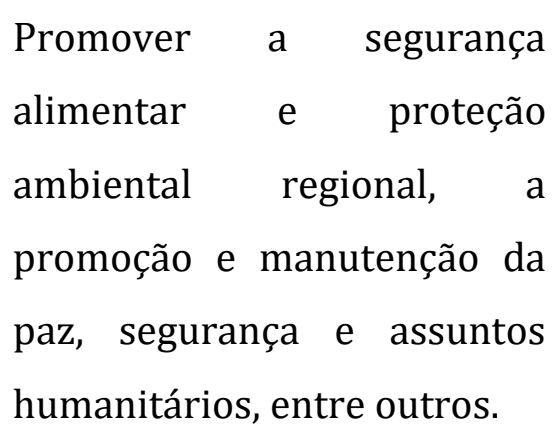 \\
\hline $\begin{array}{l}\text { Comunidade Para } \\
\text { Desenvolvimento } \\
\text { da África Austral }\end{array}$ & 1992 & $\begin{array}{c}\text { Angola, } \\
\text { Botswana, } \\
\text { República } \\
\text { Democrática do } \\
\text { Congo, Lesotho, } \\
\text { Madagáscar, } \\
\text { Maláui, Ilhas } \\
\text { Maurícias, } \\
\text { Moçambique, } \\
\text { Namíbia, Ilhas } \\
\text { Seychelles, África } \\
\text { do Sul, } \\
\text { Swazilândia, } \\
\text { Tanzânia, Zâmbia } \\
\text { e Zimbábue. }\end{array}$ & $\begin{array}{l}\text { Desenvolvimento } \\
\text { crescimento económico; } \\
\text { alívio da pobreza; } \\
\text { melhoramento do padrão e a } \\
\text { qualidade de vida dos povos } \\
\text { da região; apoiar as pessoas } \\
\text { socialmente desfavorecidas } \\
\text { através da integração } \\
\text { regional; promover e } \\
\text { defender a paz e segurança, } \\
\text { entre outros. }\end{array}$ \\
\hline
\end{tabular}

Fonte: Elaborado Pelo Autor (2016) com base na informação disponível nos websites das organizações regionais africanas ${ }^{9}$.

De acordo com os dados patentes na tabela acima, sobretudo em relação aos objetivos das organizações regionais africanas, pode-se constatar que existem um

\footnotetext{
${ }^{9}$ www.maghrebarabe.org; www.ecowas.int; www.ceeac-eccas.org; www.igad.int; e www.sadc.int, consultados em outubro de 2016.
} 
conjunto de denominadores comuns relacionados diretamente com os princípios de cooperação política, econômica e a preocupação em relação a resolução pacífica de disputas e conflitos. Em relação a esse ponto, Abbott e Snidal (1998) ${ }^{10}$, citados por Gabriela, 2013, p. 309) ressaltam que "as organizações internacionais são atores importantes em episódios críticos da política internacional, mas com poder na mediação, resolução de conflitos, manutenção da paz, bem como na aplicação de sanções, entre outras situações concretas". Para além disso, as organizações regionais africanas preocupam-se também com a promoção da paz, segurança e desenvolvimento, assuntos que estão diretamente relacionado com cooperação, integração e a prevenção, gestão e resolução de conflitos.

Desde a década de 1980, os blocos regionais africanos foram encarados como sendo mecanismos de integração regional com capacidade de oferecer oportunidades para lidar com possíveis situações de expansão de mercado africano, criação de economias de escala e a diversificação da base econômica dos Estados africanos, podendo assim contribuir para a redução da dependência externa dos mesmos. Como resultado, a cooperação econômica regional foi encarada como um arranjo institucional regional para proteção de mercados regionais africanos, oferecendo espaços para a expansão econômica, fatores de produção, produção industrial e realização do comércio regional. Todavia, as aspirações e mandatos destas organizações regionais africanas sempre refletiram diretamente os seus diversos graus de integração ${ }^{11}$ regional de cada bloco, tendo em conta os custos e benefícios do processo e as reais condições de cooperação regional, ocorrência de conflitos e a as ações dos Estados com maior poder e capacidade na respetiva sub-região africana.

Os conflitos nos Estados e entre Estados das sub-regiões africanas afetaram sobremaneira o desempenho e os esforços de integração entre 1960 e 1990. A prevenção, gestão e resolução de conflitos aparecem como um dos pilares importantes nas estratégias continentais e regionais de cooperação para a materialização dos

${ }^{10}$ ABBOTT, K. and SNIDAL, D. Why States Act through Formal International Organizations. The Journal of Conflict Resolution 42:1, February, 1998, PP. 2-32.

${ }^{11}$ Os blocos regionais africanos de integração regional encontram-se em diversos pontos de integração. Uns encontram-se ainda na fase da criação da Área de Comércio Livre como é o caso da SADC, outros na fase de União Aduaneira, como é o caso da SACU, enquanto outros ainda já possuem um Mercado Comum, como é o caso da COMESA ou a da fase de União Econômica, como é o caso da UEMOA. 
objetivos e interesses comuns dos Estados africanos. Devido à complexidade de alguns conflitos que ocorreram nos blocos regionais africanos, os diversos processos de prevenção, gestão e resolução desses conflitos na África, tiveram o envolvimento não só das próprias organizações regionais, mas também de outras organizações internacionais, como é o caso das Nações Unidas e da União Africana. Estas organizações internacionais têm-se envolvido em conflitos internos específicos, desde a independência dos Estados africanos. Por exemplo, a ONU interveio na resolução da guerra em Moçambique, na guerra civil angolana, no processo de independência da Namíbia, no caso do Sahara Ocidental, no genocídio de Ruanda. Nestes casos, as intervenções tiveram sucessos, como os casos de Moçambique e Namíbia. Mas tiveram grandes desafios e entraves nos casos de Angola, Sahara Ocidental e Ruanda. A maior parte dessas intervenções das Nações Unidas foram nos moldes de promoção e manutenção da paz.

Em relação as organizações regionais africanas de forma específica, existe uma forte cooperação entre elas e com a União Africana, para materializar os mecanismos que configuram a arquitetura de segurança africana. Como resultado dessa cooperação, os blocos de integração regional criaram os seus instrumentos próprios para prevenir, gerir e resolver conflitos, na sua região, bem como para a promoção da paz e segurança regional. Por exemplo, a SADC criou o Órgão Para Cooperação nas Áreas de Política, Defesa e Segurança; o Comitê Interministerial de Defesa e Segurança; a Troika, o Comitê Interestatal de Política e Diplomacia; o Pacto de Defesa Mútua; entre outros instrumentos. A CEDEAO criou os Mecanismos para Prevenção, Gestão e Resolução de Conflitos e Manutenção da Paz e Segurança; Conselho de Mediação e Segurança; Missão de Defesa e Segurança; Conselho de Sábios; Grupo de Monitoramento Executivo de Cessar-Fogo e Sistema de Alerta Antecipado Para Observação da Paz e Segurança, entre outros mecanismos. A Comunidade de Cooperação da África Central criou o Conselho de Paz e Segurança da África Central; Comissão de Defesa e Segurança e a Força Multinacional Centro-Africana.

A OUA, que depois transformou-se em União Africana, pouco interveio nos conflitos africanos, devido a sua doutrina sagrada de não-interferência nos assuntos internos dos Estados membros. A instituição continental pautou-se por uma postura 
mais conservadora como pontua Foltz (1991, p. 349) e menos interventiva. A natureza dos conflitos africanos condicionou, sobremaneira, a atuação da OUA, como foram os casos dos conflitos na República do Congo, em 1993, após problemas eleitorais e o conflito no Burundi, após o assassinato do Presidente, em outubro de 1993, o que seguiu um período de instabilidade e violência política maciça. Em termos práticos, na OUA houve uma abordagem de gestão de conflitos assentada em intenções a para manutenção da paz, redução e eliminação da violência, em vez de esforços para resolver as questões fundamentais e profundas que dividiam as partes envolvidas nos diversos conflitos. Por exemplo, as forças de manutenção de paz enviadas para República Centro-Africano (1996), Sudão (2004-2006, relacionadas ao conflito de Darfur) e na Somália (2007) são casos claros de medidas temporárias, em vez de abordagens efetivas de prevenção, gestão e resolução de conflitos africanos.

Juntamente com Cohen (1996, p. 23), pode-se pontuar que seja qual for o caso, as intervenções da OUA nos processos de manutenção da paz foram seriamente prejudicada por três princípios fundamentais, a saber, o respeito excessivo pelo princípio da não-interferência nos assuntos internos dos Estados membros; a questão da integridade territorial e não ingerência nos assuntos internos dos Estados; e finalmente o princípio da intangibilidade e inviolabilidade das fronteiras herdadas da colonização, previstos no Artigo $3^{\text {o }}$ da Carta da Organização da Unidade Africana OUA. No período da vigência da OUA foi criado a Comissão Para Mediação, Conciliação e Arbitragem de Conflitos, entre os Estados Membros, mas sempre que houve tensões profundas, sobretudo, que envolvesse Estados com membros na comissão. Não houve avanços para ações concretas, fazendo com que se optasse por grupos ad hoc para mediar, conciliar ou arbitrar conflitos. Devido à falta de eficácia desta comissão, a mesma foi dissolvida em 1970 e foi criada uma Comissão Ad Hoc Para Resolução de Disputas Interafricanas, em 1977.

Antes dessas iniciativas, na década de 1960, houve tentativas de criação de um Comando de Defesa Conjunto que funcionaria a partir de Burquina Faso. Para além disso, em 1965, houveram tentativas de criação de um Alto Comando Africano Conjunto, que funcionaria como uma estrutura militar unificada, sobretudo, para libertar territórios ocupados por estrangeiros. Em 1975, houve a iniciativa da criação 
de uma Organização Africana de Defesa e, finalmente, em 1979, para criação da Força Africana de Defesa. Todas essas iniciativas fracassaram, devido as principais correntes que existiam na Organização da Unidade Africana, nomeadamente, Grupo de Brazzaville, Grupo de Casablanca e Grupo de Monróvia.

Somente, nos primeiros anos da primeira década de 2000, em Durban, é que foi criada a União Africana e com ela o Conselho de Paz e Segurança que veio provocar profundas transformações normativas e institucionais na organização continental. Em termos práticos, como refere Bah et. al. (2014, p.21), a transformação da OUA para União Africana é atribuível às mudanças no quadro da política, paz e segurança, bem como nas novas necessidades socioeconômicas da África, no contexto das mudanças globais mais amplas após o final da Guerra Fria. Um dos apectos importantes dessas mudanças tem a ver com as alterações significativas no quadro normativo e institucional da União Africana, a mudança do conceito de segurança, tanto a nível regional quanto global, passando de uma visão tradicional e restrita, para uma visão ampla e abrangente, centrada na segurança humana, sem descurar a do Estado

Os constrangimentos que a OUA enfrentou relacionados com o princípio da não intervenção nos assuntos internos dos Estados e respeito pela soberania foram superados com a instauração do princípio de intervenção do Conselho de Paz e Segurança da União Africana, sobretudo para situações relacionadas com a responsabilidade de proteger, em conflitos nos quais ocorre a violação massiva dos direitos humanos e mudanças políticas inconstitucionais, com potencialidade para degenerar em violência política organizada, conflitos violentos e guerras. Em termos práticos, o Conselho de Paz e Segurança da União Africana pode intervir de forma rápida em casos de genocídio, crimes de guerra e crimes contra a humanidade, com base no seu mandato estabelecido no Artigo 7, conjugado com os Artigo 3ำ12 e 6ำ13 do Protocolo Constitutivo (2003), respectivamente:

${ }^{12}$ ARTICLE 3 - OBJECTIVES: The objectives for which the Peace and Security Council is established shall be to: promote peace, security and stability in Africa, in order to guarantee the protection and preservation of life and property, the well-being of the African people and their environment, as well as the creation of conditions conducive to sustainable development; anticipate and prevent conflicts. In circumstances where conflicts have occurred, the Peace and Security Council shall have the responsibility to undertake peacemaking and peacebuilding functions for the resolution of these conflicts; promote and implement peacebuilding and post-conflict reconstruction activities to consolidate peace and prevent the resurgence of violence; co-ordinate and harmonize continental efforts in the prevention and combating of international 
Antecipar e evitar disputas e conflitos, bem como políticas, que podem levar ao genocídio e crimes contra a humanidade; realizar atividades de restauração e consolidação da paz, para resolver conflitos onde eles ocorreram; autorizar a montagem e envio de missões de paz e definir as orientações gerais para a condução de tais missões, incluindo o mandato; recomendar à Assembleia, nos termos do artigo 4 (h) do Ato Constitutivo da União Africana, a intervenção, em nome da União, num Estado-Membro, em caso de circunstâncias graves, nomeadamente, crimes de guerra, genocídio e crimes contra a humanidade, tal como definido nos instrumentos internacionais relevantes; aplicar sanções sempre que ocorra uma mudança inconstitucional de governo num Estado-Membro; implementar política de defesa comum da União Africana; garantir a implementação das convenções e instrumentos fundamentais para combater o terrorismo internacional; promover a harmonização e coordenação de esforços entre os mecanismos regionais e da União Africana relativos a promoção da paz, segurança e estabilidade, em África; fazer acompanhamento e promoção de práticas democráticas, boa governação, o Estado de direito, proteção dos direitos humanos e liberdades fundamentais e respeito pela dignidade da vida humana e do direito internacional humanitário; promover e incentivar a implementação de convenções e tratados de controle de armas e desarmamento; examinar e tomar medidas, em situações onde a independência nacional e soberania de um Estado-Membro seja ameaçada por atos de agressão, incluindo por mercenários; e apoiar e facilitar ações humanitárias, em situações de conflitos armados ou de catástrofes naturais (AFRICAN UNION, 2006, p. 56).

O Conselho de Paz e Segurança da União Africana14 é um órgão de decisão para questões relacionadas com a prevenção, gestão e resolução de conflitos. Trata-se de um mecanismos de segurança coletiva e um arranjo de alerta destinado a articular e facilitar respostas rápidas e eficientes em situações de crises e conflitos na África. Este órgão é um dos pilares fundamentais para a configuração da arquitetura de segurança da União Africana, que em termos genéricos, é o mecanismo para a promoção da paz, segurança e estabilidade continental.

terrorism in all its aspects; develop a common defense policy for the Union, in accordance with article 4(d) of the Constitutive Act; promote and encourage democratic practices, good governance and the rule of law, protect human rights and fundamental freedoms, respect for the sanctity of human life and international humanitarian law, as part of efforts for preventing conflicts.

${ }^{13}$ ARTICLE 6 - FUNCTIONS: The Peace and Security Council shall perform functions in the following areas: a. promotion of peace, security and stability in Africa; early warning and preventive diplomacy; peace-making, including the use of good offices, mediation, conciliation and enquiry; peace support operations and intervention, pursuant to article $4(h)$ and $(j)$ of the Constitutive Act; peace-building and post-conflict reconstruction; humanitarian action and disaster management; any other function as may be decided by the Assembly.

${ }^{14}$ Este conselho é o órgão sucessor da Comissão de Mediação, Conciliação e Arbitragem da OUA, que era órgão Central de Prevenção, gestão e resolução da organização. O sucessor da referida comissão foi estabelecido pelo Artigo 5 (2) do Ato Constitutivo da União Africana de 2000. O Protocolo relativo à criação do Conselho de Paz e Segurança foi adotado em 09 de julho de 2002, em Durban, África do Sul, e entrou em vigor em dezembro de 2003. Este instrumento tornou-se totalmente operacional no início de 2004. 
No âmbito da prevenção, gestão e resolução de conflitos na África, as operações de paz são um elemento de análise importante. Desde o início da década de 2000, quase uma dezena de operações de paz foram levadas a cabo pela União Africana, no âmbito das ações do Departamento de Paz e Segurança, sendo responsável pelo planejamento, implantação, sustentação e liquidação da operação. Todavia, em muitos casos devido a constrangimentos financeiros, as missões passaram para a responsabilidade das Nações Unidas. A maioria dos mandatos de operação foram periodicamente revistos, com o número de contingentes militares, policial e pessoal de apoio a administração pública a sofrer mudanças e rotações. Para suportar as operações foi criado o Fundo da Paz, previsto no Artigo $21^{15}$ do Protocolo que estabelece o Conselho de Paz e Segurança da União Africana, parceiros internacionais e, em alguns casos, contribuições do orçamento de paz das Nações Unidas ONU.

Entre as missões de paz levadas a cabo pela União Africana importa destacar a Missão de Paz da União Africana na Somália - AMISOM ${ }^{16}$, estabelecida pelo Conselho de Paz e Segurança da UA, em 19 de janeiro de 2007, para apoiar as instituições estatais no processo de transição política, diálogo e reconciliação nacional; facilitar assistência humanitária; e criar condições propícias para a estabilização da paz a longo prazo, a reconstrução e desenvolvimento nacional. A outra missão das União Africana foi a missão conjunta entre a União Africana e as Nações Unidas em Darfur - UNAMID. Esta missão conjunta foi estabelecida em resposta à contínua situação de violência na região de Darfur, no Sudão. Ela foi estabelecida em junho de 2007 e substituiu a Missão da União Africana no Sudão - PSC/PR/COMM/LXXIX - e a Resolução 1769 de 2007. 0

${ }^{15}$ ARTICLE 21 - FUNDING (Peace Fund): 1. In order to provide the necessary financial resources for peace support missions and other operational activities related to peace and security, a Special Fund, to be known as the Peace Fund, shall be established. The operations of the Peace Fund shall be governed by the relevant Financial Rules and Regulations of the Union. 2. The Peace Fund shall be made up of financial appropriations from the regular budget of Union, including arrears of contributions, voluntary contributions from Member States and from other sources within Africa, including the private sector, civil society and individuals, as well as through appropriate fund raising activities. 3. The Chairperson of the Commission shall raise and accept voluntary contributions from sources outside Africa, in conformity with the objectives and principles of the Union. 4. There shall also be established, within the Peace Fund, a revolving Trust Fund. The appropriate amount of the revolving Trust Fund shall be determined by the relevant Policy Organs of the Union upon recommendation by the Peace and Security Council.

${ }^{16}$ Esta missão foi, igualmente, mandatada sob égide do Conselho de Segurança nas Nações Unidas, através da Resolução do Conselho de Segurança da ONU 1744 de 2007, onde o mandato inicial da AMISOM era de por seis meses, mas que depois foi prorrogado várias vezes, sendo a mais recente a que ocorreu em 7 de julho de 2016, quando o Conselho de Segurança autorizou os Estados Membros da UA a manter a implantação AMISOM até 31 de maio de 2017 - Resolução do CSNU 2297. 
mandato da UNAMID foi, inicialmente, por um ano, mas depois foi ampliado pela resolução 2296 do Conselho de Segurança das Nações Unidas de junho de 2016.

Houve uma iniciativa para a Erradicação do Exército de Resistência do Senhor (RCI/LRA), um grupo terrorista, em novembro de 2011, através da Resolução PSC/PR/COMM/CCCXXI, visto que Estados como República Centro-Africana, República Democrática do Congo, Sudão do Sul e Uganda eram afetados pelas operações do LRA. Esta iniciativa visava a eliminação do LRA e a criação de um ambiente propício para a estabilização e recuperação das áreas afetadas. Para além dessa iniciativa, a União Africana levou a cabo uma missão de suporte internacional na República CentroAfricana, conhecida como MISCA, estabelecida em 19 de julho de 2013, através da Resolução PSC/PR/COMM2/CCCLXXXV. Esta operação foi aprovada e autorizada pelo Conselho de Segurança das Nações Unidas, através da Resolução 2127 de 5 de dezembro de 2013.

A União Africana levou a cabo a Missão de Suporte Internacional no Mali, conhecida como AFISMA. Esta missão foi uma operação conjunta entre a União Africana e a Comunidade Económica dos Estados da África Ocidental (CEDEAO), através do mandatado emitido pelo Comunicado PSC/AHG/COMM/2/CCCLIII de 25 de janeiro de 2013. AFISMA foi mandatada, igualmente, pela Resolução do CSNU 2085 de 20 de dezembro de 2012. 0 núcleo duro do mandato da AFISMA era fornecer apoio às autoridades do Mali, na restauração da autoridade do Estado; apoiar a preservação da unidade nacional do Mali e a integridade territorial; fornecer proteção aos civis, reduzir a ameaça dos grupos terroristas; apoiar as autoridades do Mali na implementação do roteiro de transição; e ajudar as autoridades do Mali a reformar os setores de defesa e segurança.

Nas Ilhas Comores, a União Africana levou a cabo uma Missão de Assistência Eleitoral e Segurança conhecida como MAES, estabelecida pelo Comunicado PSC/MIN/COMM1/LXXVII de 9 de maio de 2007, que autorizou o envio a missão com o mandatado de apoiar a criação de um ambiente seguro, para a realização de um conjunto de eleições; monitorar os processos eleitorais; incentivar o diálogo entre os principais atores políticos e ajudar e facilitar a restauração da autoridade do Governo naquele Estado insular do Oceano Índico. Depois de períodos de escalada de violência 
política pós-eleitoral, o mandato da MAES foi revisto em outubro de 2007 e prorrogado por seis meses, com a tarefa de restaurar as autoridades constitucionais e ajudar na edificação de um ambiente de segurança interna favorável. Em março de 2008, antes do final do mandato, houve a intervenção das forças do MAES, lideradas pela tropas da Tanzânia e Sudão, para restaurar a democracia.

Finalmente, temos a primeira Missão de Paz da União Africana que ocorreu no Burundi e que é conhecida como AMIB. Esta missão foi autorizada em 2003 pelo Órgão Central do Mecanismo de Prevenção, Gestão e Resolução da OUA, que funcionava enquanto se aguarda a criação do Conselho de Paz e Segurança da União Africana. A AMIB tinha como mandatado central fiscalizar, observar, monitorar e verificar a implementação do acordo de cessar-fogo, para consolidação da paz em Burundi. No decurso da missão, o comando das operações saiu da União Africana, paras as Nações Unidas. Entre 2003 e 2004, a AMIB realizou a tarefas que lhe são confiadas pelo Órgão Central, sobretudo a garantia do cessar-fogo.

Em seguida, são apresentadas as experiências específicas de três organizações regionais africanas - SADC, CEDEAO e IGAD - no que concerne a prevenção, gestão e resolução de conflitos nos seus blocos regionais. As três organizações possuem mecanismos específicos de prevenção, gestão e resolução de conflitos que foram desenvolvidos e implementados tendo em conta as experiências regionais de lidar com conflitos. Cada uma das organizações teve a sua história específica, o que fez com que a experiência de prevenir, gerir e resolver conflitos, bem como promover a paz e segurança regional fosse específica e peculiar, não obstante, de pautarem por mecanismos pacíficos, a ameaça e o uso da força esteve sempre presente e foi sempre uma alternativa.

\section{Experiências da SADC na Prevenção, Gestão e Resolução de Conflitos}

A SADC é uma organização de integração regional dos Estados da região da África Austral composta por quinze membros: Angola, Botswana, República Democrática do Congo, Lesotho, Madagáscar, Maláui, Ilhas Maurícias, Moçambique, Namíbia, Ilhas Seychelles, África do Sul, Suazilândia, Tanzânia, Zâmbia e Zimbábue. 0 processo de integração regional remonta os anos 1970, com a criação da Linha da Frente que tinha como objetivo central proporcionar a libertação dos Estados da região 
austral de África do sistema colonial. Com a independência de Moçambique e Angola, em 1975, houve um alargamento da Linha da Frente que, em 1980, com a independência do Zimbábue, transformou-se em SADCC, uma organização de coordenação setorial a nível regional, com o objetivo de reduzir a dependência da África do Sul. Em 1992, a organização de coordenação setorial transformou-se numa organização de integração regional, neste caso a SADC.

A SADCC, enquanto fase evoluída da Linha da Frente e da SADC, surge de um contexto específico, marcado pelos efeitos das agressões e pressões políticas, econômicas e militares do Regime do Apartheid na África do Sul, que procurava impor seus valores nos restantes Estados da região; manter a sua hegemonia interna, em relação a uma maioria negra; e conter o avanço do Comunismo na região. Estas ações do Regime do Apartheid foram operacionalizadas pelo Constellation of Southern African Plan States ${ }^{17}$. Foi para contrariar as tendências hegemônicas do Apartheid da África do Sul que o processo de integração regional surge na região da África Austral, como uma forma de estreitar laços econômicos e políticos, para fazer face às pressões do regime racista sul-africano. Com o fim do Apartheid na África do Sul e a independência da Namíbia em 1990, surge a SADC, uma organização de integração regional com novos objetivos e novas estratégias.

Inicialmente a organização estava voltada para questões econômicas e para o desenvolvimento regional. Em 1996, foi criado o Órgão para Cooperação nas Áreas de Política, Defesa e Segurança. A partir deste momento, a SADC passou a ter uma estrutura econômica e outra de defesa e segurança. Esta última passou a ser responsável pela prevenção, gestão e resolução de conflitos. No início, para os conflitos internos nos Estados membros, a tendência das lideranças foi de recursos ao uso da força, através de intervenções militares, não obstante de existirem apologistas do uso

${ }^{17}$ Plano de Constelação dos Estados da África Austral, um plano concebido e desenvolvido nos círculos militares pelo então Ministro da Defesa P. W. Botha. Quando Botha ascendeu ao posto de PrimeiroMinistro, passou ao conceito de Constelação dos Estados da África Austral e tornou política oficial do estado sul-africano, em 1978. A política actuava em três vertentes: Militar - no campo doméstico foi desenvolvida a National Security Manegemment (NSMS) e, no campo exterior, a actuação foi através de patrocínios a movimentos de sublevação nos Estados vizinhos com vista a criar desestabilização; Diplomática - actuava através de assinatura de acordos de não-agressão e boa vizinhança; e Económica atuava através de uma "guerra económica" com os Estados vizinhos de modo a criar vulnerabilidades económicas internas e uma dependência económica directa. O fim último da estratégia era criar uma constelação de Estados na África Austral (NHABINDE, 1999, p. 15-20). 
de mecanismos pacíficos. No caso do Congo, em 1998, Zacarias (1997, p. 48) refere que “alguns Estados como Zimbábue, Angola e Namíbia defendiam uma ação militar para repelir a agressão do Ruanda e Uganda, enquanto outros preferiam um processo de cessar-fogo e conversações de paz".

0 recurso a intervenção militar foi um elemento dominante nas discussões das lideranças regionais sobre a prevenção, gestão e resolução de conflitos internos na região. Em 1998, no Lesotho, diante de uma situação de conflito político e alteração da ordem constitucional que perfazia um golpe de Estado, houve uma invasão militar liderada pela África do Sul e Botswana, com o intuito de repor a ordem naquele Estado. Com o andar do tempo, as lideranças fundadoras da SADC, quando confrontadas com a possibilidade de intervenções militares nos seus Estados, começaram a discutir seriamente as intervenções militares e a sua possibilidade de interferir nos assuntos internos dos Estados membros e a promoção da paz e segurança regional.

Na SADC convivem Estados com vários sistemas políticos, desde democracias duradouras até monarquias com tendências a autocracia. Para além disso, há Estados fundadores da organização e outros que se juntaram a mesma mais tarde. Não obstante, aos vários constrangimentos que os Estados membros da organização enfrentam, eles sentem a necessidade de unir esforços com vista a alcançar a paz, segurança e desenvolvimento regional. Todavia, os interesses e os alinhamentos dos Estados têm influenciado nos processos de prevenção, gestão e resolução de conflitos. Por exemplo, nas crises políticas pós-eleitoral no Zimbábue e Madagáscar, houveram divergências em relação aos mecanismos de resolução de conflitos a serem empregados - intervenção militar ou meios pacíficos. Em ambos os casos, a abordagem da SADC acabou centrada nos mecanismos pacíficos de prevenção, gestão e resolução de conflitos, baseados na mediação, facilitação e bons ofícios.

Normalmente, quando se está diante de um conflito interno num dos Estados que faz parte do núcleo fundador da organização, há sempre dificuldades em decidir entre intervir ou não intervir. A África do Sul e o Zimbábue foram sempre os Estados que mais influenciaram as decisões de intervenção com recurso a ameaça ou uso da força. Moçambique foi sempre usado como um instrumento diplomático, tendo em conta o sucesso que teve de duas décadas de paz, depois de uma guerra devastadora. 


\section{Experiências da CEDEAO na Prevenção, Gestão e Resolução de Conflitos}

A CEDEAO é uma organização de integração regional da África Ocidental composta por quinze Estados membros - Benim, Burkina Faso, Cabo Verde, Costa do Marfim, Gâmbia, Gana, Guiné Conacri, Guiné Bissau, Libéria, Mali, Níger, Nigéria, Senegal, Serra Leoa e Togo. O desejo de combinar esforços políticos e econômicos sempre foi reconhecido como um passo para a prosperidade da região. Os primeiros esforços de integração regional remontam a 1945, com a criação do Franco CFA, que proporcionou aos Estados francófonos da região uma união monetária. Em 1964, o Presidente liberiano, William Tubman, propôs uma união econômica para a África Ocidental, levando a um acordo que foi assinado em 1965, por quatro Estados - Costa do Marfim, Guiné Conacri, Libéria e Serra Leoa. Em 1972, os presidentes da Nigéria e do Togo percorreram a região em apoio à ideia de integração e daí surgiram as bases do Tratado de Lagos de 1975, que deu origem a CEDEAO. O Tratado de Lagos, inicialmente era limitado a questões econômicas, mas os acontecimentos políticos emergentes levaram à sua revisão e com isso a sua expansão em 1993.

Vários princípios orientam esta organização regional de integração. No Artigo 418 do Tratado da CEDEAO, pode-se destacar o princípio da "não-agressão entre Estados membros; a manutenção da paz, estabilidade e segurança regional, através da promoção e fortalecimento de relações de boa-vizinhança; a solução pacífica de controvérsias entre os Estados membros, através de uma ativa cooperação e promoção de um ambiente de paz como um pré-requisito para o desenvolvimento econômico". Todos esses princípios fazem parte de um conjunto de instrumentos para promoção da

18 "The high contracting parties, in pursuit of the objectives stated in Article 3 of this Treaty, solemnly affirm and declare their adherence to the following principles: a) equality and inter-dependence of Member States; $b$ ) solidarity and collective self-reliance; $c$ ) inter-State co-operation, harmonization of policies and integration of programmers; non-aggression between Member States; e) maintenance of regional peace, stability and security through the promotion and strengthening of good neighborliness; $f$ ) peaceful settlement of disputes among Member States, active co-operation between neighboring countries and promotion of a peaceful environment as a prerequisite for economic development; $g$ ) recognition, promotion and protection of human and peoples' rights in accordance with the provisions of the African Charter on Human and Peoples' Rights; h) accountability, economic and social justice and popular participation in development; i) recognition and observance of the rules and principles of the Community; j) promotion and consolidation of a democratic system of governance in each Member State as envisaged by the Declaration of Political Principles adopted in Abuja on 6 July, 1991; and k) equitable and just distribution of the costs and benefits of economic co-operation and integration" (ECOWAS, 2010) 
paz, segurança e estabilidade regional, bem como para a prevenção e resolução de conflitos entre os Estados membros.

Todavia, desde o período das independências, a região Ocidental de África foi marcada por períodos longos de conflitos e violência organizada, uma vez que sempre que terminou uma guerra civil num Estado, o outro iniciou outra, houve um golpe de Estado ou violência pós-eleitoral. Por exemplo, quando terminou a guerra, na Libéria, houve o golpe de Estado na Guiné-Bissau; e quando terminou a guerra na Serra Leoa, iniciou a violência política na Costa do Marfim; quando terminou a violência política neste Estado, surgiram os ataques terroristas do Boko Haram, entre outras situações.

Tendo em conta o quadro de conflitualidade e instabilidade permanente acima apresentado, a CEDEAO decidiu criar uma estrutura militar cuja missão é a de ser uma força de paz. É neste contexto que surge a ECOMOG - Ecowas Cease-Fire Minitoring Group. Para Berman e Sam (2000, p. 83), "a falta de um aparato funcional de segurança combinado com uma determinação dentro do pequeno grupo de Estados da CEDEAO para intervir, militarmente, em apoio os membros, deu ímpeto para a criação de uma nova estrutura chamada ECOMOG". Portanto, pode-se notar que a gênese deste braço militar da organização está relacionada diretamente com os imperativos de paz e segurança.

De acordo com o no 02 do Artigo 18 do Protocolo Sobre Defesa e Assistência Mútua, assinado pelos Estados membros da CEDEAO em 29 de maio de 1989, “os Estados membros não são forçados a intervir militarmente se o conflito armado interno não apresentar perigo de se alastrar para fora das suas fronteiras, e se não for apoiado a partir do exterior". Desta feita, como pontua Khobe (2000, p. 106), o papel da ECOMOG centra-se claramente em intervenções armadas - peceenforcement ${ }^{19}$ e peacekeeping ${ }^{20}$ - como aconteceu na Libéria e Serra Leoa, uma vez que trata-se de uma

19 Conhecidas como missão de imposição da paz, são operações que incluem o uso de força armada na manutenção ou restauração da paz e segurança. Elas são estabelecida quando o Conselho de Segurança julga haver ameaça à paz, ruptura da paz ou acto de agressão e podem abranger intervenções de caráter humanitário: abertura de corredores humanitários (DAVID, 2001, p. 331).

${ }^{20}$ Conhecidas como missão de manutenção da paz, são acções empreendidas por militares, policiais e civis no terreno do conflito, com o consentimento das partes. Elas visam a implementação ou o monitoramento do controlo de conflitos: cessar-fogos, separação de forças e a sua solução - acordos de paz. Nessas operações, as acções são complementadas por esforços políticos, no intuito de estabelecer uma resolução pacífica e duradoura para o conflito (DAVID, 2001, p. 322). 
estrutura militar. Graças a ECOMOG, as situações políticas desesperadoras como os casos da guerra civil na Libéria e Serra Leoa puderam se caminhar para uma situação de equilíbrio, pacificação territorial e estabilização política e estatal. Como corolário, conseguiu-se levar as partes em conflito à mesa de negociações, como refere o Tenente Coronel Touré, antigo líder da Junta Militar, “a ECOMOG, que restaurou a paz, na Libéria e a ordem constitucional, na Serra Leoa, pode, construindo na sua presente posição, formar uma significativa força interafricana, podendo ser usada para estabilizar Estados e restaurar a paz" (TROURÉ, 1999, p. 26).

Desde o seu estabelecimento, a ECOMOG participou em vários acordos de pacificação de conflitos, com destaque para os Acordos de Lomé de 13 de Fevereiro de 1991, no Togo, e os de Yamossoukro de 30 de Junho a 30 de Setembro de 1991, na Costa do Marfim. Para reforçar o papel da ECOMOG, a CEDEAO criou em outubro de 1998, o Protocolo Sobre o Mecanismo Para Prevenção, Gestão e Resolução de Conflitos e sobre a Segurança e Manutenção de Paz. Estes mecanismos demonstram a intenção da organização de se preparar para prever, gerir e resolver conflitos, combinando os mecanismos pacíficos ao uso da força, consoante a casos específicos.

Em várias situações a Nigéria defendeu o recurso às intervenções militares em conflitos internos, como aconteceu no caso do envio de tropas para Libéria e "como o mandato de restaurar a lei e ordem, apesar da realidade ter provado que o objetivo era impedir a ascensão do poder por parte da FPNL 21" (KHOBE, 2000, p. 106), diferentemente dos Estados anglófonos, que mais frequentemente se mostram favoráveis à não intervenção. 0 posicionamento nigeriano pode ser explicado pelo fato de ser o Estado mais populoso, com recursos e com capacidades de intervir, militarmente, nos outros Estados.

Apesar da CEDEAO, por via da ECOMOG e seus mecanismos de prevenção, gestão e resolução de conflitos, ter conseguido pacificar conflitos na região da África Ocidental, muitas fraquezas têm sido demonstradas ao longo dos tempos. Esta organização sub-regional tem sido marcada por enormes disputas e competições pelo protagonismo entre os Estados anglófonos que a compõe. Para consubstanciar essa ideia, Khobe (2000, p. 111) refere:

\footnotetext{
${ }^{21}$ Frente Patriótica Nacional da Libéria.
} 
As rivalidades e profundas suspeições entre as classes dirigentes dos Estados da África Ocidental complicam o ambiente político. Os Estados membros, algumas vezes, recusam a participar ativamente, ou mesmo, opõem-se as operações da ECOMOG, por causa de um Estado membro rival que jogou um papel preponderante na decisão de enviar tropas ou é visto como dando crédito ao arranque inicial da operação. Noutros casos, uma declaração dando proeminência ao papel de um Estado em particular pode desencadear uma resistência e recusa de enviar tropas de outros Estados.

Pode-se constatar que as rivalidades internas sobre a proeminência nas ações da organização para prever, gerir r resolver conflitos põem em causa, em muitos casos, a realização da atividade pacificadora. 0 receio dos Estados membros da CEDEAO pelo papel dominante da Nigéria os inibe de levar a cabo várias iniciativas com vista a prever, gerir e resolver conflitos. Este receio tende a crescer, porque o domínio da Nigéria na organização pode culminar com a sua intervenção nos assuntos internos dos outros Estados.

Na África Ocidental, a CEDEAO tem desde 1990 estado envolvida em operações de manutenção da paz. Os conflitos na Libéria e Serra Leoa foram duas situações em que a CEDEAO enviou tropas com apoio financeiro e material da comunidade internacional. Apesar do enorme custo das guerras na Libéria e Serra Leoa, em termos de vidas humanas e materiais, as intervenções de manutenção da paz, voltadas principalmente para conseguir promover, estabilizar e consolidar a paz, foram sempre um enorme desafio. Não obstante a todos esses receios, fica evidente que os Estados membros da CEDEAO estão empenhados em prever, gerir e resolver conflitos internos que ocorrem na região através dos mecanismos e princípios estabelecidos pela organização. Várias foram as reuniões e cimeiras que foram organizadas com o intuito de buscar consensos, promover diálogos e firmar acordos de paz nos seus Estados membros, com destaque para Libéria, Serra Leoa, Costa do Marfim e Guiné-Bissau. Todavia, mais esforços devem ser levados a cabo com vista a aprofundar os mecanismos de prevenção, gestão e resolução de conflitos internos, combinando de forma ótima e oportuna os mecanismos pacíficos de resolução de conflitos e o uso da força, sobretudo para a imposição da paz.

\section{Experiências do IGAD na Prevenção, Gestão e Resolução de Conflitos}

O IGAD é uma organização de integração regional da África Oriental composta por oito Estados - Djibouti, Etiópia, Eritreia, Quénia, Somália, Sudão, Uganda e Sudão 
do Sul - que procuram a promoção da segurança alimentar e proteção ambiental regional, a promoção e manutenção da paz, segurança e assuntos humanitários, bem como a cooperação e integração econômica dos Estados membros, uma vez que a região da África Oriental e o Chifre de África são duas das zonas mais vulneráveis no continente africano. Estas regiões do continente são assoladas por situações de secas cíclicas e prolongadas e constituem a parte final do Deserto do Sahara. Esta situação faz com que muitos Estados seja afetados por ciclos de fome e insegurança alimentar. Esse cenário acaba por se agravar com situações de guerra civil, proliferação de grupos terroristas, pirataria marítima e desintegração de Estados, como é o caso da Somália. Este quadro dificulta os planos regionais para fazer face a esta situação.

Apesar das dificuldades políticas, militares e securitárias, Djibuti, Etiópia, Quénia, Somália, Sudão e Uganda decidiram unir forças para fazer face aos desafios regionais e em 1986 foi criada a Autoridade Intergovernamental Para a Seca e Desenvolvimento - IGAD. Em Setembro de 1993, Eritreia integrou-se à organização. Em Abril de 1995, em Adis Abeba, a Conferência dos Chefes de Estado e de Governo da organização fez uma declaração para revitalizar IGADD e ampliar a cooperação entre os Estados membros. No dia 21 de Março de 1996, em Nairóbi, na Conferência dos Chefes de Estado e de Governo, foi assinada o Acordo de Emenda do IGADD, que passou a instituir a IGAD revitalizada e com um novo nome: A Autoridade Intergovernamental para o Desenvolvimento. A organização revitalizada expandiu as áreas de cooperação regional e criou uma nova estrutura organizacional. Assim, em 1996, foi criada a Autoridade Intergovernamental Para o Desenvolvimento - IGAD - na África Oriental, em substituição à Autoridade Intergovernamental sobre Seca e Desenvolvimento IGADD.

Centrada no lema da "promoção da paz, prosperidade e integração regional", o Artigo $6^{22}$ do Tratado que estabelece o IGAD definiu como um dos seus objetivos centrais a promoção da paz e a estabilidade regional, a partir da criação de

22 "The Member States solemnly reaffirm their commitment to the following principles: the sovereign equality of all Member States; non-interference in the internal affairs of Member States; the peaceful settlement of inter- and intra-State conflicts through dialogue; maintenance of regional peace, stability and security; mutual and equitable sharing of benefits accruing from cooperation under this agreement; recognition, promotion and protection of human and people's rights in accordance with the provisions of the African Charter on Human and People's Rights" (IGAD, 1996). 
mecanismos regionais para a prevenção, gestão e resolução de conflitos intra e interestatais, através do diálogo. Em relação aos seus objetivos relacionados com a prevenção, gestão e resolução de conflitos internos, Berman e Sams (2000, p. 207) referem que:

Como outras organizações sub-regionais, em África, o IGAD virou subsequentemente as suas ações e suas atenções à questão da paz e segurança. O IGAD começou os seus esforços de mediação para terminar o conflito somali, em 1991. Em 1993, em nome dos membros, Etiópia foi mandatada para tomar a dianteira e acompanhar os desenvolvimentos e ajudar a encontrar uma solução diplomática.

Em 1995, o IGAD adotou o mecanismo de Resolução de Conflitos. Em termos políticos, o IGAD foi um instrumento importante para a pacificação do Sudão, Uganda e Somália, apesar de não ter conseguido sucesso no último caso. A organização fez grandes esforços e patrocinou a conferência da paz para a Somália, que ocorreu no Quénia, no início dos anos 2000. As conversações para a pacificação somali, decorreram anteriormente no Djibuti, onde se decidiu formar uma Assembleia Nacional e um Governo Provisório. Todavia, esses esforços para a pacificação da Somália não foram a bom porto.

Entre 1994 e 2002, o IGAD desempenhou um papel preponderante no processo de pacificação do Sudão, conseguindo aproximar o Governo de Cartum e o $\mathrm{SPLA}^{23}$, através de contatos e rondas negociais, como as que aconteceram em Nairóbi e Machakos, no Quénia. Todavia, as negociações foram suspensas em Setembro de 2002, com a mobilização geral das tropas sudanesas para combater o SPLA. Para além deste caso, o IGAD também levou a cabo um conjunto de esforços e démarches em relação à ao Governo de Kampala e o $\mathrm{LRA}^{24}$, com vista a solucionar as divergências entre as partes em conflito.

No caso do conflito somali, os esforços do IGAD centraram-se em proporcionar rondas de conversações. Estas conversações tiveram lugar em Djibuti, como foi referido anteriormente e que culminaram com a criação da Assembleia Nacional Transitória, composta por 245 membros ciânicos e um Presidente Interino, em Maio de 2000. Em Outubro do mesmo ano, Abdullahi Derow foi empossado para o cargo de Primeiro-Ministro. Todavia, o processo foi assombrado por várias divergências

${ }^{23}$ Sudan People's Liberation Army - Exército Popular de Libertação do Sudão

${ }^{24}$ Lord's Resistance Army - Exercito de Libertação do Senhor do Uganda. 
políticas, conflitos entre os clãs e retorno as ações armadas, pondo por terra todos os esforços levados a cabo pela organização regional, para gerir e resolver o conflito.

Recentemente, para fazer face a situações de conflitos e insegurança, o IGAD criou institutos especializados em prevenir e resolver conflitos e promover a paz e segurança na região. 0 primeiro é o CEWARN ${ }^{25}$ (Centro de Aviso Prévio de Conflitos e Mecanismos de Resposta do IGAD) e o segundo é o ISSP26 (Programa do Setor de Segurança do IGAD). 0 Centro de Aviso Prévio de Conflitos e Mecanismos de Resposta do IGAD foi criado em 2002 e afigura-se como uma ferramenta estratégica para alerta precoce de conflitos e busca de respostas imediatas para os prevenir, de modo que não tomem proporções violentas e a paz possa ser mantida. Trata-se de uma rede de excelência que trabalha para promover a redução de riscos de conflitos na região, através de um aviso prévio e estruturado e permite produzir uma consciência situacional do mesmo o que possibiliza uma intervenção em áreas prioritárias.

O Programa do Setor de Segurança do IGAD (ISSP) foi lançado em Outubro de 2011 e resulta das ações bem-sucedidas, bem como dos desafios do Programa de Construção Capacidade contra o Terrorismo (ICPAT), que foi lançado em 2006 e destinado a construção de capacidades nacionais para resistir ao terrorismo e promover a cooperação garantir a segurança regional. É composto por cinco componentes principais: reforço da capacidade judicial, cooperação interdepartamental, reforço do controle das fronteiras, treinamento e promoção estratégica de cooperação. O Programa do Setor de Segurança do IGAD tem como objetivos principais e missão estratégica promover a paz, segurança, desenvolvimento sustentável e a integração regional na região; aumentar a eficácia dos Estados membros no sector da segurança, para abordar ameaças nacionais, transnacionais e regionais comuns; melhorar a capacidade do setor da segurança dos Estados membros para enfrentar as ameaças comuns; e contribuir para a previsão, antecipação, prevenção e gestão ameaças emergentes na região.

É importante pontuar que no caso da guerra no Sudão do Sul, o colapso da Estado na Somália, os conflitos em Ruanda, em Burundi e a situação na Etiópia, bem

\footnotetext{
${ }^{25}$ IGAD's Conflict Early Warning and Response Mechanism.

${ }^{26}$ IGAD Security Sector Program.
} 
como as guerras no Congo, são exemplos significativos de conflitos prolongados que desafiaram os mecanismos de prevenção, gestão e resolução de conflitos das organizações regionais africanas. A intensidade destes conflitos foi abordada de forma muito superficial, onde as intervenções diplomáticas tinham maior privilégio do que outros mecanismos de gestão e resolução de conflitos, que envolvem diversas agências e atores.

Estas intervenções acabaram por banalizar o papel das organizações regionais nos processos de prevenção, gestão e resolução de conflitos na África, bem como a necessidade de se abordar de forma mais profunda as preocupações das partes envolvidas direta e indiretamente nos conflitos. Por exemplo, vários tribunais instituídos parecem ter sido destinados a punir indivíduos selecionados e que poderiam causar situações de instabilidade aos governos instaurados, servindo assim, aos interesses de atores poderosos envolvidos nos conflitos. Os tribunais de crimes de guerra instaurados nos conflitos Ruanda, Burundi, Serra Leoa ou Libéria desempenharam o seu papel, mas em muitos casos deixaram muito a desejar

No caso da guerra no Sudão do Sul, a intervenção do IGADD/IGAD no Djibouti foi mais intermitente do que incisiva. Apesar da existência de questões de base colonial neste conflito, era difícil para muitos buscar soluções duradouras, abordando as causas profundas do conflito. Como aponta Cohen (1996, p. 4) ao afirmar que "a África Oriental, em geral, foi uma região onde nem a União Africana, nem a comunidade internacional tem sido capaz de avançar com processos de gestão de conflitos significativos, além da intervenção humanitária”.

\section{Considerações Finais}

Pode-se constatar que as organizações regionais africanas tiveram sempre alguma sensibilidade para lidar com processos de prevenção, gestão e resolução de conflitos nos e entre os Estados membros, sobretudo para evitar que a violência tome proporções incontroláveis. Todavia, essa sensibilidade foi quase que sempre condicionada pelos princípios normativos de não ingerência em assuntos internos dos Estados membros, princípio norteador essas organizações, fazendo com que elas se limitassem a promover mecanismos diplomáticos e pacíficos para a prevenção, gestão e resolução de conflitos. Todavia, ainda há preocupações complexas e profundas que 
devem ser abordadas de forma concreta, para que a contribuição das organizações regionais africanas e da própria União Africana sejam mais eficientes e duradouras na prevenção, gestão e resolução de conflitos em África.

Não obstante as suas limitações, as organizações internacionais regionais africanas constituem um importante instrumento para a promoção da paz, desenvolvimento, estabilidade e segurança regional na África, por um lado, e por outro, elas são importantes mecanismos de prevenção, gestão e resolução de conflitos internos nos seus Estados membros. Elas demonstram enormes potencialidades para promover e manter um clima de paz e estabilidade, através da promoção de políticas, valores e princípios que conduzem a uma maior aproximação das partes que se encontram em disputas e conflitos internos. Nos seus protocolos e outros mecanismos de prevenção, gestão e resolução de conflitos, as organizações internacionais regionais privilegiam os mecanismos pacíficos de resolução de conflitos, oferecendo os bons ofícios e a mediação basicamente, mas em casos extremos e excecionais recorre-se a intervenção militar através do peaceenforcement e do peacekeeping. Todavia, a unidade e vontade regional são elementos basilares e de capital importância para prever, gerir e resolver conflitos internos nos Estados membros de uma organização regional.

Para que as iniciativas de prevenção, gestão e resolução de conflitos internos seja efetiva na África, é necessário que haja vontade política das lideranças em conflito. É preciso que todas as divergências e o espírito de incumprimento dos acordos e compromissos assinados sejam deixados para trás. As partes devem encarar-se como parceiros e não inimigos, na prossecução da paz, desenvolvimento e segurança. As organizações internacionais são relevantes sim, mas os atores dos conflitos são as preponderantes importantes e indispensáveis para todo o sucesso das ações com vista a prever, gerir e resolver conflitos de forma efetiva e definitiva.

Uma questão crítica nos processos de prevenção, gestão e resolução de conflitos na África tem a ver com casos nos quais há intervenções de atores externos, como são os casos das negociações de paz na Angola na década de 1990, coordenadas por Portugal entre 1990-1992; os esforços de mediação da guerra dos dezesseis anos em Moçambique, levados a cabo pelos italianos entre 1990 e 1992; e os esforços dos Estados Unidos em relação à Etiópia em 1990-1991 e na Somália em 1992-1993, entre 
outros casos; o patrocínio de conferências por parte da França e da Grã-Bretanha em 1994-1995, para facilitar o diálogo sobre o desenvolvimento de consenso sobre política e gestão de conflitos ao e África; as intervenções militares da França nas suas colônias com vista a conseguir "estabilizar a paz" nomeadamente, a Costa do Marfim (2003 e 2010), Chad (2008), Mali (2013) ou na República Centro Africana, entre outros casos. Todos esses são exemplos de intervenção de atores externos nos processos de resolução de conflitos em África.

\section{Referências Bibliográficas}

AFRICAN UNION COMMISSION. African Union Handbook 2017: A Guide For Those Working With and Within the African Union. Addis Ababa- Ethiopia: African Union Commission, 2017.

AFRICAN UNION. Peace and Security Council (PSC). The African Union Commission. Addis Ababa: UA, 2003.

BAH, Alhaji Sarjoh; CHOGE-NYANGORO, Elizabeth; DERSSO, Solomon; MOFYA, Brenda e MURITHI, Tim. Handbook of the African Peace and Security Architecture. Addis Ababa Office and the African Union. Addis Ababa: Friedrich-Ebert-Stiftung, 2014

BERMAN, Eric G. e SAMS, Katie E. Peacekeeping in Africa: Capabilities and Culpabilities. Geneve \& Pretoria: United Nation Institute For Disarmament Research and Institute For Security Studies, 2000.

BOURTON, John. Conflict: Resolution and Prevention. New York: St. Martin's Press, 1990.

CAVALCANTE, Milene Dantas. Conflitos Internacionais. Departamento de Relações Internacionais. Santa Catarina: UFSC, 2001.

COHEN, Herman J. Conflict Management in Africa. CSIS Africa Notes 181, Washington, DC, fevereiro, 1996.

DAVID, Charles-Philippe. A Guerra e a Paz: Abordagens Contemporâneas de Segurança e da Defesa. Lisboa: Instituto Piaget, 2001.

DIAS, Reinaldo. Relações Internacionais: Introdução ao Estudo da Sociedade Internacional Global. São Paulo: Editora Atlas, 2010.

FOLTZ, William J. The Organization of African Unity and the Resolution of Africa's Conflicts. In: Deng and Zartman (Eds). Conflict Resolution in Africa. Washington, D.C: The Brookings Institution, 1991.

GABRIELA, Sterian Maria. The Role of International Organizations in the Global Economic Governance - An Assessment. Romanian Economic and Business Review Special Issue, 2013. P. 308-316. 
GASPAR, António da Costa (2004). O Papel da Família na Promoção da Paz e Resolução de Conflitos: Chibuto, Jangamo, Inharrime, Manjacaze e Zavala. Volume 2, OREC - Organização Para a Resolução de Conflitos. Maputo: DINAME, 2004.

GASPAR, António da Costa. Diagnóstico de Focos de Origem de Conflitos Sociais nas comunidades Urbanas e Periféricas. Organização Para resolução de Conflitos. Maputo: Editora DINAME, 2003.

HERBST, Jeffrey. States and Power in Africa: Comparative Lesson in Authority and Control. New Jersey: Princeton University Press, 2000.

HERZ, Mônica e Hoffmann, Andrea Ribeiro. Organizações Internacionais: História e Práticas. Rio de Janeiro: Elsevier, 2004.

IGAD. Agreement Establishing the Inter-Governmental Authority on Development. Assembly of Heads of State and Government. IGAD/SUM-96/AGRE-Doc Nairobi, 21 March 1996.

MARTINELLI, Dante e ALMEIDA, Ana Paula de. Negociação e solução de conflitos: do Impasse ao Ganha-Ganha do Melhor Estilo. São: Atlas. São Paulo, 1998.

NHABINDE, Simeão Amosse. Desestabilização e Guerra Económica no Sistema Ferro-Portuário de Moçambique, 1980 - 1997. Maputo: Livraria Universitária da Universidade Eduardo Mondlane, 1999.

ORGANIZAÇÃO DAS NAÇÕES UNIDAS. Manual de Resolução de Conflitos. 1a Edição. Livraria do Centro de Resolução de Conflitos. ONU: Nova Iorque, 2001.

TROURÉ, Amadou Toumani. Obstacles to Comprehension and Barriers to the Mastery of Conflicts. In ADEDEJI, Adebayo (Ed). Comprehending and Mastering African Conflicts: the Search for Sustainable Peace and Good Governance. London \& New York: Zed Book in Association with African Centre for Development and Strategic Studies, 1999. 